\title{
Chemical control of field horsetail (Equisetum arvense)
}

\author{
T.K. James and A. Rahman \\ Ruakura Research Centre, Private Bag 3123, Hamilton 3420, New Zealand \\ Corresponding author: trevor.james@agresearch.co.nz
}

\begin{abstract}
Field horsetail is a perennial, rhizomatous weed with summer-growing fern-like foliage and sporelating stems. It likes moist, free-draining sandy soils and gravel riverbeds and flood plains. Glasshouse experiments on 10-month old potted field horsetail plants showed excellent efficacy of imazapyr, amitrole, metsulfuron, picloram and combinations of picloram with metsulfuron or triclopyr, all at highest recommended rates. However, in the field trial, single applications of these herbicides did not provide effective long-term control with significant regrowth 2 months after treatment. This suggests that most of the herbicide treatments did not damage the extensive root system sufficiently to stop considerable regrowth, with herbicides such as triclopyr+picloram, glyphosate and metsulfuron failing to give adequate control of this weed in the field. Further applications of amitrole or triclopyr+metsulfuron 2 months after the initial treatment gave better results but also killed all other vegetation.
\end{abstract}

Keywords Equisetum arvense, field horsetail, chemical control, herbicide.

\section{INTRODUCTION}

Field horsetail (Equisetum arvense) is a fernlike plant that regrows each summer from its underground root structure (Marshall 1986). It can grow to $800 \mathrm{~mm}$ tall but normally is only $300-400 \mathrm{~mm}$. When its rhizomes are plentiful it forms a thick mat underground, which makes it extremely competitive to other plants over the summer months. Field horsetail grows best in free draining, sandy soils and is usually associated with river banks, drains and other moist areas. Although, it sporulates freely, it appears that its primary mode of spread is vegetative and in Manawatu field horsetail has become widely distributed via river gravels that are used for roading, paths and building construction. It is also readily spread down river by floods.

There appears to be a dearth of recent publications on the control of field horsetail, possibly because some $40-50$ years ago it was claimed that several herbicides readily controlled this weed (Hoyt \& Carder 1962; Patterson 1965; Ryan 1976). The recommended herbicides were amitrole, picloram and dichlobenil respectively. However, Bell \& Popay (1988) tested all the above herbicides, along with glyphosate, and found only dichlobenil had significant effect on the growth of field horsetail. Used at $5.5 \mathrm{~kg}$ ai/ ha it reduced top growth by $95 \%$ the following spring, while the high rate of $11 \mathrm{~kg}$ ai/ha reduced top growth to zero. More recently, Torstensson \& Börjesson (2004) reported success in controlling field horsetail with imazapyr, while Ainsworth et al. (2006) successfully used the dimethylamine salt formulation of MCPA.

The aim of the trials reported here was to evaluate some alternate herbicides for the 
control of field horsetail, firstly by testing a range of herbicides on potted plants and secondly by evaluating the best of them in the natural ecosystem.

\section{MATERIALS AND METHODS}

\section{Regrowth of root fragments in glasshouse}

This experiment was carried out with fresh roots on 6 December 2005. The 2-3 mm thick rhizomatous roots were randomly cut into lengths of 10-50 $\mathrm{mm}$. Ten replicates of each were placed in trays in damp vermiculite. Roots were removed when they sprouted and after 3 months all remaining fragments were assessed for decay.

\section{Control of potted plants}

Rhizome sections were collected fresh from the field and planted into $150 \mathrm{~mm}$ diameter pots on 7 December 2005. The plants were grown through the summer to build up root mass and then allowed to senesce in autumn. Regrowth from the dormant, over-wintered rhizomes was treated on 2 October 2006 when they were 30$40 \mathrm{~cm}$ tall with multiple shoots per pot. Each treatment (Table 1) was replicated on six plants. Treatments $2-13$ were foliar applications of the herbicides applied with a pressurised garden sprayer until the foliage was wet but avoiding runoff (about 1000 litres/ha). For Treatments 14 and 15 , prills were placed in a single lot at the centre of the pot. Treated plants were scored for phytotoxicity to existing and new shoot growth at intervals over a 7 month period. The score system was based on an assessment of the overall appearance of the plant with special emphasis on the amount of brown or dead leaf material and the size of the plant compared to the untreated controls. Treatments were only given a 100\% score if all the stems had collapsed and rotted to ground level. Most of the herbicides tested were selected on the basis of reported efficacy in the literature and were generally used at the highest recommended label rate and in combination with the recommended adjuvant. Aminopyralid and the triclopyr+metsulfuron combination were included as they were new herbicides or combinations of similar chemistry to the other herbicides tested.

\section{Control of field plants}

The field trial was conducted at Flockhouse near Bulls on a Himatangi Black Sand. The trial of four,

Table 1 Herbicide treatments used on potted E. arvense plants.

\begin{tabular}{lllccc}
\hline No. & Treatment & Product name & (Rate $\%$ a.i. $)$ & Adjuvant & $\begin{array}{c}\text { Rate }(\mathrm{v} / \mathrm{v} \\
\text { carrier }\end{array}$ \\
\hline 1 & Untreated & - & - & - & - \\
2 & Imazapyr & Arsenal & $0.125 \%$ & Pulse & $0.2 \%$ \\
3 & Triclopyr + picloram & Conquest & $0.18+0.06 \%$ & Pulse & $0.2 \%$ \\
4 & Triclopyr + metsulfuron & Ultimate & $0.09+0.03 \%$ & Pulse & $0.2 \%$ \\
5 & Aminopyralid & Tordon Max & $0.018 \%$ & Pulse & $0.2 \%$ \\
6 & Metsulfuron & Escort & $0.03 \%$ & Pulse & $0.2 \%$ \\
7 & Glyphosate & Roundup Transorb & $0.378 \%$ & Pulse & $0.2 \%$ \\
8 & Glyphosate & Roundup Transorb & $0.756 \%$ & Pulse & $0.2 \%$ \\
9 & Amitrole & Activated Amitrole & $1.8 \%$ & Li700 & $0.1 \%$ \\
10 & Amitrole & Activated Amitrole & $3.6 \%$ & Li700 & $0.1 \%$ \\
11 & MCPA & Agritone 720 & $0.16 \%$ & - & - \\
12 & MCPA & Agritone 720 & $0.16 \%$ & Pulse & $0.2 \%$ \\
13 & MCPA & Agritone 720 & $0.4 \%$ & - & - \\
14 & Picloram prills & Tordon 2D & $0.02 \mathrm{~g} /$ pot & - & - \\
15 & Picloram prills & Tordon 2D & $0.04 \mathrm{~g} / \mathrm{pot}$ & - & - \\
\hline
\end{tabular}


blocked replicates was laid out in a single strip along the edge of a stream. Individual plots were $2 \mathrm{~m}$ wide and from 3 to $6 \mathrm{~m}$ long. The treatments (Table 2) were applied with a pressurised garden sprayer at a rate that lightly wetted the foliage (about 600 litres/ha) on 13 February 2008 when the air temperature was $26^{\circ} \mathrm{C}$, soil temperature was $20^{\circ} \mathrm{C}$ and it was sunny with no wind. On 4 April 2008 (2 months after the first application) the treatments were re-applied at the same rates to any regrowth on the same plots. At this time the air temperature was $22^{\circ} \mathrm{C}$, soil temperature $19^{\circ} \mathrm{C}$, there was $50 \%$ cloud cover and a slight breeze. The following year on 27 March 2009 (13 months after the first application), MCPA was applied to Treatments 3 and 5, while triclopyr + picloram was applied to Treatments 4, 6 and 8 . Both herbicides were applied at double the rate previously used. At the time the air temperature was $21^{\circ} \mathrm{C}$, soil temperature $19^{\circ} \mathrm{C}$ and it was sunny with wind gusts up to $8 \mathrm{~m} / \mathrm{s}$. At application ground cover of field horsetail was between 50$90 \%$ in each plot. After treatment the plots were visually assessed for reduction in top-growth of field horsetail, compared to the nearest untreated control plot, once or twice a year by two observers and the results averaged. The final assessment was 12 months after the last herbicide application.

All data were subjected to ANOVA to separate treatment means.

\section{RESULTS AND DISCUSSION} Regrowth of root fragments in glasshouse

The regrowth of Equisetum arvense was related to rhizome fragment length. The percent of rhizome fragments that sprouted and grew were $10,10,10,30$ and $70 \%$ for the $10,20,30,40$ and 50 $\mathrm{mm}$ length fragments respectively. On inspection after 3 months it was found that the fragments of rhizome that had not sprouted had decayed. It is most likely the shorter root lengths failed to grow because there were no buds or nodes present on the shorter fragments.

\section{Control of potted plants}

In this experiment, six of the candidate herbicides, viz. imazapyr, triclopyr+picloram, triclopyr+metsulfuron, metsulfuron, amitrole and picloram, resulted in $100 \%$ control of this weed although their speed of action varied considerably (Table 3). MCPA and aminopyralid both gave $100 \%$ shoot mortality at 8 and 14 weeks after treatment respectively, but considerable regrowth occurred in these treatments after this time. Glyphosate activity also peaked at about 14 weeks after treatment but never achieved complete shoot mortality and by the final assessment there was also considerable regrowth in these pots.

\section{Control of field plants}

Results from the field were less successful. None of the treatments achieved the same level of efficacy as with the potted plants, with considerable regrowth occurring in most plots (Table 4). As there was considerable regrowth in most plots 2 months after the first treatments were applied, it was decided to re-apply the treatments with the intention that removing the vegetative re-growth

Table 2 Herbicide treatments used in the field trial (first and second applications).

\begin{tabular}{llccc}
\hline No. & Treatment & Rate $(\%$ a.i. $)$ & Adjuvant & $\begin{array}{c}\text { Rate }(\mathrm{v} / \mathrm{v} \\
\text { carrier })\end{array}$ \\
\hline 1 & Untreated & - & - & - \\
2 & Glyphosate + fluroxypyr & $0.54+0.17 \%$ & - & - \\
3 & Amitrole & $3.6 \%$ & Li700 & $0.1 \%$ \\
4 & Metsulfuron & $0.03 \%$ & Pulse & $0.2 \%$ \\
5 & MCPA & $0.16 \%$ & - & - \\
6 & Aminopyralid & $0.018 \%$ & Pulse & $0.2 \%$ \\
7 & Triclopyr + metsulfuron & $0.09+0.03 \%$ & Pulse & $0.2 \%$ \\
8 & Triclopyr + picloram & $0.18+0.06 \%$ & Pulse & $0.2 \%$ \\
\hline
\end{tabular}


Table 3 Control (\%) of E. arvense potted plants at 5, 9, 15, 22 and 26 weeks after treatment with various herbicides.

\begin{tabular}{|c|c|c|c|c|c|c|}
\hline \multirow[b]{2}{*}{ Treatment } & \multirow[b]{2}{*}{ Rate (\% a.i.) } & \multicolumn{5}{|c|}{ Weeks after treatment } \\
\hline & & 5 & 9 & 15 & 22 & 26 \\
\hline Untreated & - & 0 & 0 & 0 & 0 & 0 \\
\hline Imazapyr & $0.125 \%$ & 40 & 28 & 73 & 100 & 100 \\
\hline Triclopyr+picloram & $0.18+0.06 \%$ & 95 & 100 & 100 & 100 & 100 \\
\hline Triclopyr+metsulfuron & $0.09+0.03 \%$ & 94 & 100 & 100 & 100 & 100 \\
\hline Aminopyralid & $0.018 \%$ & 70 & 90 & 100 & 90 & 87 \\
\hline Metsulfuron & $0.03 \%$ & 50 & 35 & 77 & 96 & 100 \\
\hline Glyphosate & $0.378 \%$ & 55 & 55 & 88 & 87 & 75 \\
\hline Glyphosate & $0.756 \%$ & 53 & 78 & 99 & 67 & 57 \\
\hline Amitrole & $1.8 \%$ & 60 & 74 & 98 & 98 & 97 \\
\hline Amitrole & $3.6 \%$ & 60 & 72 & 80 & 100 & 100 \\
\hline MCPA & $0.16 \%$ & 80 & 100 & 99 & 79 & 78 \\
\hline MCPA & $0.16 \%$ & 95 & 100 & 98 & 67 & 57 \\
\hline MCPA & $0.4 \%$ & 94 & 100 & 96 & 68 & 63 \\
\hline Picloram prills & $0.02 \mathrm{~g} / \mathrm{pot}$ & 33 & 73 & 98 & 99 & 98 \\
\hline Picloram prills & $0.04 \mathrm{~g} /$ pot & 58 & 73 & 98 & 98 & 100 \\
\hline LSD $(\mathrm{P}<0.05)$ & & 4.2 & 5.9 & 11.4 & 9.0 & 7.5 \\
\hline
\end{tabular}

late in the season would reduce the root biomass going into winter. An assessment 4 weeks later (Table 4) showed that the second application did achieve $100 \%$ shoot mortality of the plant regrowth in some treatments. However, by the following spring (34 weeks after treatment, Table 4) only two treatments, amitrole and triclopyr+metsulfuron, had greater than 50\% reduction in plant re-growth. By autumn there was substantial regrowth in all treatments except for amitrole so the decision was made to re-treat several of the plots. The two most successful treatments, amitrole and triclopyr+metsulfuron, had killed most of the other vegetation present, so it was decided not to retreat these plots with the same herbicides, but with an alternative that would not inhibit the growth of the newly emerged grasses. Thus on 27 March 2009 (34 weeks after the initial treatment) MCPA or triclopyr+picloram were used but at twice the rate of the first application (Table 4). This strategy did not work either, as 1 year later (110 weeks after treatment, Table 4) all but a single treatment were not different from the untreated control plots, despite having received three herbicide applications over 2 years.

The most successful treatment, amitrole, only reduced above ground plant growth by about twothirds and removed other vegetation for much of the duration of the trial. Thus, this treatment could not be viewed as environmentally friendly as these plots could be prone to erosion if large areas were treated. By the end of the trial (March 2010), after a less damaging herbicide was used in the final year, all the plots again had 100\% vegetation cover. The predominant species present at this time were white clover (Trifolium repens) and tall fescue (Schedonorus arundinaceus). Both these are desired species and compare favourably with the vegetation remaining in other treatments. Untreated control, metsulfuron, triclopyr+metsulfuron, triclopyr+picloram, aminopyralid and MCPA treatments were mostly dominated by Mercer grass (Paspalum distichum) 
Table 4. Control (\% shoot mortality cf. untreated) of E. arvense in the field trial at 4, 7, 11, 34, 58 and 110 weeks after treatment with various herbicides.

\begin{tabular}{|c|c|c|c|c|c|c|c|c|}
\hline \multirow[b]{2}{*}{ No. } & \multirow[b]{2}{*}{ Treatment $^{1}$} & \multirow[b]{2}{*}{ Rate (\% a.i.) } & \multicolumn{6}{|c|}{ Weeks after treatment } \\
\hline & & & 4 & 7 & 11 & 34 & 58 & 110 \\
\hline 1 & Untreated & - & 0 & 0 & 0 & 0 & 0 & 0 \\
\hline 2 & Glyphosate+fluroxypyr & $0.54+0.17 \%$ & 58 & 35 & 64 & 20 & 0 & 0 \\
\hline 3 & Amitrole & $3.6 \%$ & 95 & 99 & 100 & 84 & 64 & 65 \\
\hline 4 & Metsulfuron & $0.03 \%$ & 54 & 76 & 81 & 50 & 15 & 10 \\
\hline 5 & MCPA & $0.16 \%$ & 59 & 40 & 99 & 5 & 0 & 5 \\
\hline 6 & Aminopyralid & $0.018 \%$ & 0 & 0 & 72 & 0 & 0 & 0 \\
\hline 7 & Triclopyr+metsulfuron & $0.09+0.03 \%$ & 89 & 92 & 100 & 75 & 13 & 10 \\
\hline 8 & Triclopyr+picloram & $0.18+0.06 \%$ & 71 & 73 & 100 & 43 & 18 & 0 \\
\hline \multicolumn{2}{|c|}{ LSD 5\% } & & 20.7 & 17.4 & 19.9 & 16.7 & 18.5 & 14.2 \\
\hline
\end{tabular}

${ }^{1}$ Treatments were re-applied to the same plots on 4 April 2008 ( 7 weeks after the start of the trial respectively). On 27 March 2009 (58 weeks after the start of the trial) MCPA was applied to Treatments 3 and 5 while triclopyr+picloram was applied to Treatments 4, 6 and 8, both herbicides at double the rate previously used.

while glyphosate+fluroxypyr was dominated by white clover, ryegrass (Lolium spp.) and tall fescue.

Considering that in some plots all the top growth was desiccated by the herbicide treatment, then lack of control could only be due to the herbicides used having little activity on the extensive root system of this weed and also to a favourable environment for regrowth. The trial was located adjacent to a water body so there was always sufficient water for growth. All the treatments were applied in late summer or autumn in the field trial, which is recommended as the best time to obtain translocation and activity against the root system due to the significant rhizome growth at this time (Marshall 1986). The results from other studies showed greater levels of control (Hoyt \& Carder 1962; Patterson 1965; Ryan 1976) but they were conducted in cropping areas where there are water and other stresses to aid herbicide efficacy.

Imazapyr gave good control of the potted field horsetail plants in Experiment 1, similar to that reported by Torstensson \& Börjesson (2004), when they used it on railway embankments. However, this herbicide was not evaluated in the field trial as it was no longer commercially available in New Zealand. It is also a highly soluble and mobile compound and care would need to be exercised if used adjacent to waterways (Rahman et al. 1993). Dichlobenil and picloram were not evaluated in the field as the high application rates of the prill formulation makes them very expensive and impractical to apply over large areas. The dimethylamine salt formulation of MCPA was less successful in this experiment than reported by Ainsworth et al. (2006), but they only used it on potted plants, with no field testing.

The single field trial described here was a severe test for the herbicides evaluated, and conditions when the herbicides were applied were often less than optimal as they usually are in these situations. The field horsetail plants were partially shielded from the spray by other plants, atmospheric conditions determined that the spray solution dried rapidly on the plant surface allowing reduced time for uptake and after treatment there was little contribution from competition, shading or other factors to aid the herbicide. There is probably little to be gained by simply increasing the rate or frequency of application in controlling this weed but as it was 
demonstrated that under some conditions there are effective herbicides, then progress is more likely to be made by determining how to improve herbicide deposition and translocation in field locations.

\section{CONCLUSION}

In some field situations where the root growth of field horsetail is restricted due to cultivation or other means, and is thus more like the growth of field horsetail in the pot experiment, herbicidal control is likely to be more effective, but the best herbicides are generally not very selective to other plant species and could result in considerable collateral damage. However, in field situations where field horsetail is well established and has an extensive root system, effective control with herbicides is very difficult and is likely to involve many repeat applications of very damaging herbicides that are likely to kill all other vegetation present at the time.

\section{ACKNOWLEDGEMENTS}

We wish to thank the Department of Conservation for funding this project, Erin Carney for assistance with the glasshouse trials and Don Clark and Craig Davey of Horizons Regional Council for assistance with the field trail.

\section{REFERENCES}

Ainsworth N, Gunasekera L, Bonillo J 2006. Management of horsetail species using herbicides. Proceedings of the $15^{\text {th }}$ Australian Weeds Conference: 279-282.

Bell CC, Popay AI 1988. Chemical control of field horsetail. Proceedings of the $41^{\text {st }}$ New Zealand Weed and Pest Control Conference: 66-69.

Hoyt PB, Carder AC 1962. Chemical control of field horsetail. Weeds 10: 111-115.

Marshall G 1986. Growth and development of field horsetail (Equisetum arvense L.). Weed Science 34: 271-275.

Patterson TM 1965. Departmental trials with picloram. Proceedings of the $18^{\text {th }} \mathrm{New}$ Zealand Weed and Pest Control Conference: 24-31.

Rahman A, Sanders P, James TK 1993. Persistence and mobility of imazapyr in some New Zealand soils. Proceedings of the 8th EWRS Symposium, Braunschweig, Germany. Pp. 493-500.

Ryan GF 1976. Chemical control of field horsetail. Weed Science 24: 401-404.

Torstensson L, Börjesson E 2004. Use of imazapyr against Equisetum arvense on Swedish railway tracks. Pest Management Science 60: 565569. 